\title{
ПІДХОДИ ЩОДО РОЗРОБКИ МОДЕЛІ ФУНКЦІОНУВАННЯ АГЕНТСТВ 3 ОЦІНКИ МЕДИЧНИХ ТЕХНОЛОГІЙ В УКРАЇНІ
}

\author{
() І. О. Федяк, О. В. Максименко \\ ДВНЗ «Івано-Франківський національний медичний університет»
}

\begin{abstract}
Резюме: у статті висвітлено різні погляди трактування поняття «оцінка медичних технологій»; обґрунтовано актуальність та своєчасність створення агентств з НТА в Україні на національному, регіональному та локальному рівнях і запропоновано підходи щодо розробки моделі їх функціонування. Ці підходи доцільно розглядати у площині перетину психологічних, соціальних, законодавчих, організаційних, ринкових аспектів захисту інтересів окремої людини і суспільства в цілому.
\end{abstract}

Ключові слова: оцінка технологій охорони здоров'я, агентства з ОТОЗ.

Вступ. Сучасний період реформування в Україні системи охорони здоров'я (СО3) та підходів до надання медичної і фрармацевтичної допомоги ставить в епіцентр вимог до послуг, які надаються, необхідність ефективності, безпечності, економічності як на рівні окремого споживача послуг - громадянина, так і на національному рівні. Тому в останній час поняттю «Оцінка технологій охорони здоров'я» (ОТОЗ) надається стільки уваги як окремими науковцями, науковими школами, так і органами держаної влади.

Як сказано у Проекті Резолюції круглого столу у Верховній Раді України на тему «ОТОЗ як інструмент підвищення якості медичної допомоги та раціонального використання ресурсів», «головною метою системи оцінки технологій охорони здоров'я (Hеalth Technology Assessment - HTA) $є$ надання науково обгрунтованої інорормації для осіб, які визначають політику і приймають управлінські рішення в СОЗ» (05.02.2016 р.) [1].

11-17 липня 2016 р. відбувся тренінг для Експертного комітету 3 відбору та використання основних лікарських засобів (ОЛЗ) на тему «Оцінка медичних технологій», що був організований проектом «Системи покращеного доступу до ЛЗ та фрармацевтичних послуг», який фрінансується Агенцією США 3 міжнародного розвитку та міжнародним фрондом «Відродження». Запрошені іноземні тренери актуалізували значення НТА у сучасному світі та перспективи його упровадження для країн, які розвиваються [2].

Теоретичні питання НТА висвітлювали у своїх працях як іноземні, так і вітчизняні науковці: Kristensen F. B., 2006 [3]; Sorenson K., 2008 [4]; Baравікова О. А., 2009 [5]; Заліська О. М., Парновський Б. Л., 2010 [6]; Немченко А. С., Косяченко К. Л., 2011 [7, 8]; Воробьев К. П., 2013 [9]; Яковлєва Л. В., Міщенко О. Я., 2013 [10]; Угрехелидзе Д. Т., Ягуди- на Р. И., 2015 [11, 12], Заліська О. М., Піняжко О. Б., 2015 [13], Думенко Т. М., Садовнича О. О., 2016 [14]. Водночас дана стаття присвячена питанню практичного запровадження ОТОЗ в Україні шляхом створення триступеневих Агентств з ОТОЗ.

Мета дослідження: базуючись на аналізі даних доступних джерел літератури, обґрунтувати актуальність створення Агентств з ОТОЗ в Україні на даний час та розробки моделей їх функціонування.

Методи дослідження: бібліографічний, системно-логічний.

Результати й обговорення. На сьогодні в Україні терміном «оцінка медичних технологій» (OMT) або, у більш широкому контексті, «оцінка технологій охорони здоров'я» оперують і політики, і журналісти, і науковці, і представники сорери О3 (лікарі, провізори, управлінці галузі різних рівнів) [1]. За результатами опрацювання джерел літератури нами був зроблений аналіз підходів до визначення змісту цього поняття у різних авторів (табл. 1).

Отже, не існує єдиного загальноприйнятого тлумачення цього терміну, однак усі визначення єдині в постулаті, що немає потреби у МТ як такій - потреба $€$ в кінцевому її результаті для здоров'я і якості життя людини. Тому у резолюціях та інших програмних документах різних організацій в системі менеджменту, громадського спостереження або контролю в СО3 за останні 30 років помітна зміна вектора від більш «інженерного», «орієнтованого на ринок» уявлення про МТ до «медичного», «гуманістичного», що включає всі компоненти лікувального процесу та фрармацевтичної опіки пацієнта [5].

Країни ЄС та США визначили головне завдання СО3 на найближчі десятиліття - скорочення захворюваності і управління здоров'ям. Очевидно, що при такій перспективі необхідно вести мову про повну зміну

ISSN 2312-0967. Pharmaceutical review. 2016. № 4 
Таблиця 1. Визначення ОМТ за різними авторами

\begin{tabular}{|c|c|c|}
\hline Рік & Автор & Визначення \\
\hline 1991 & $\begin{array}{l}\text { Міжнародне товариство } \\
\text { фармакоекономічних } \\
\text { досліджень (International } \\
\text { Society for Pharmacoeconomis } \\
\text { and Outcomes Research) }\end{array}$ & $\begin{array}{l}\text { ОМТ - це мультидисциплінарний процес, який узагальнює інфрормацію } \\
\text { про медичні, соціальні, економічні та етичні аспекти при використанні } \\
\text { медичних технологій (МТ) (схеми профрілактики, діагностики, лікування) } \\
\text { у системній, прозорій, неупередженій формі. Метою ОТМ є надання } \\
\text { керівникам ОЗ даних про безпечні та ефективні засоби для досягнення } \\
\text { вищої цінності - здоров'я }[6,8]\end{array}$ \\
\hline 2006 & Kristensen F. B. & $\begin{array}{l}\text { Мета ОМТ - допомогти в розробці безпечної, ефективної політики } \\
\text { О3, яка орієнтована на потреби хворих і прагне досягти найкращого } \\
\text { вкладення коштів. Незважаючи на зв'язок із політикою О3, ОМТ } \\
\text { повинна міцно спиратися на дослідні дані і науковий метод [3] }\end{array}$ \\
\hline 2009 & Варавікова О. А. & $\begin{array}{l}\text { ОМТ - це міжнародний напрямок науки, методологія дослідження та } \\
\text { аналізу нових МТ. } \\
\text { Вона заснована на переконанні, що наукові дослідження співзвучні із } \\
\text { проблемами СОЗ, а не з інтересами окремих дослідників, а також на } \\
\text { тому, що науковий прогрес повинен включати етичні норми і принципи } \\
\text { [5] }\end{array}$ \\
\hline 2010 & $\begin{array}{l}\text { Організація з міжнародних } \\
\text { оцінок медичних технологій } \\
\text { (Health Technology Assessment } \\
\text { International) }\end{array}$ & $\begin{array}{l}\text { ОМТ - це галузь наукових досліджень, результати яких повинні } \\
\text { допомогти у прийнятті політичних та клінічних рішень щодо } \\
\text { впровадження та поширення МТ. Це методологія, яка включає аналіз } \\
\text { технологій в СО3 з точки зору економічного, клінічного, етичного, } \\
\text { епідеміологічного аспектів [15] }\end{array}$ \\
\hline 2011 & Косяченко К. Л., Немченко А. С. & $\begin{array}{l}\text { ОМТ - це мультидисциплінарний процес впровадження наукових } \\
\text { знань для обґрунтування ефективних рішень в СОЗ. Система ОМТ } \\
\text { направлена на узагальнення інфрормації про нові і діючі технології } \\
\text { на основі принципів системності, прозорості, об'єктивності, } \\
\text { обґрунтованості й незалежності. ОМТ направлена на допомогу } \\
\text { регуляторам, які приймають політичні рішення щодо застосування } \\
\text { технологій, закупівлі лз [7,8] }\end{array}$ \\
\hline 2016 & $\begin{array}{l}\text { ПроектРезолюції круглогостолу } \\
\text { «Оцінка ОТОЗ як інструмент } \\
\text { підвищення якості медичної } \\
\text { допомоги та раціонального } \\
\text { використання ресурсів» }\end{array}$ & $\begin{array}{l}\text { Головною метою ОТОЗ є надання науково обґрунтованої інформації } \\
\text { для управлінців у СОЗ для вибору ЛЗ, ВМП, імунобіологічного, } \\
\text { профрілактичного, діагностичного засобу, методів діагностики та } \\
\text { лікування, найбільш економічно доступних з оптимальним показником } \\
\text { витрати / есрективність в умовах обмеженого фінансування СОЗ [1] }\end{array}$ \\
\hline 2016 & $\begin{array}{l}\text { Думенко Т. М., } \\
\text { Садовнича О. О. }\end{array}$ & $\begin{array}{l}\text { ОТОЗ - мультидисциплінарна галузь аналізу політик, яка вивчає } \\
\text { медичні, соціальні, етичні та економічні наслідки розвитку, } \\
\text { використання та розповсюдження МТ. ІІї мета: засноване на інформації } \\
\text { прийняття рішень щодо запровадження та/або реімбурсації нових МТ, } \\
\text { яке базується на наукових доказах [14] }\end{array}$ \\
\hline
\end{tabular}

підходів до виділення пріоритетних напрямів розвитку системи ОЗ та його фрінансування. Тому в основі новітніх концепцій лежить теза про те, що фрінансування СО3 повинне мати характер не витрат, а інвестицій, що зумовлює перехід від концепції розвитку ОЗ «Health is Cost» (здоров'я коштує грошей) до нової «Health is Wealth» (здоров'я - це добробут). Tому змінюється і модель фінансування СО3: від «Treatment Based» (спрямованої на проведення процедур) до «Patient Centered» (пацієнтцентричної) [16].

На даний час СО3 в Україні перебуває у періоді реорганізації як структурної, так і підходів до фрінансування, а, найголовніше, - концептуальної. Тому, взявши за основу прогресивні ідеї людиноцентричної парадигми побудови СО3, нами запропонована модель обґрунтування необхідності запровадження методології ОМТ у вітчизняну практику відбору МТ (рис. 1).

Отже, як випливає з рисунка 1, концептуально-методологічний підхід до актуалізації проведення ОТОЗ в Україні, як і інституцій (агентств), які її здійснюва- тимуть, лежить у площині перетину психологічних, соціальних, законодавчих, організаційних, ринкових аспектів захисту інтересів окремого громадянина, певної територіальної громади і держави загалом.

Для повноцінного фрункціонування ОМТ в Україні необхідна відповідна законодавча база, яка забезпечить централізований державний підхід до використання результатів наукових робіт. Адже на даний час ОТО3 переважно представлена висновками наукових досліджень докторських та кандидатських праць. А цілісна науково-практична методологія ОТМ як i єдиний координаційний центр з ОТОЗ у нашій державі відсутні [1].

Поряд $з$ цим певне підґрунтя процесу запровадження методології ОМТ у СОЗ в Україні вже закладено. На користь цього свідчить і чимала кількість публікацій з питань ОМТ у вітчизняній фраховій періодиці, і створення у 2012 р. безбюджетного громадсько-ініціативного Українського агентства з ОМТ О3, і проведення тематичних конференцій, круглого столу

ISSN 2312-0967. Фармацевтичний часопис. 2016. № 4 


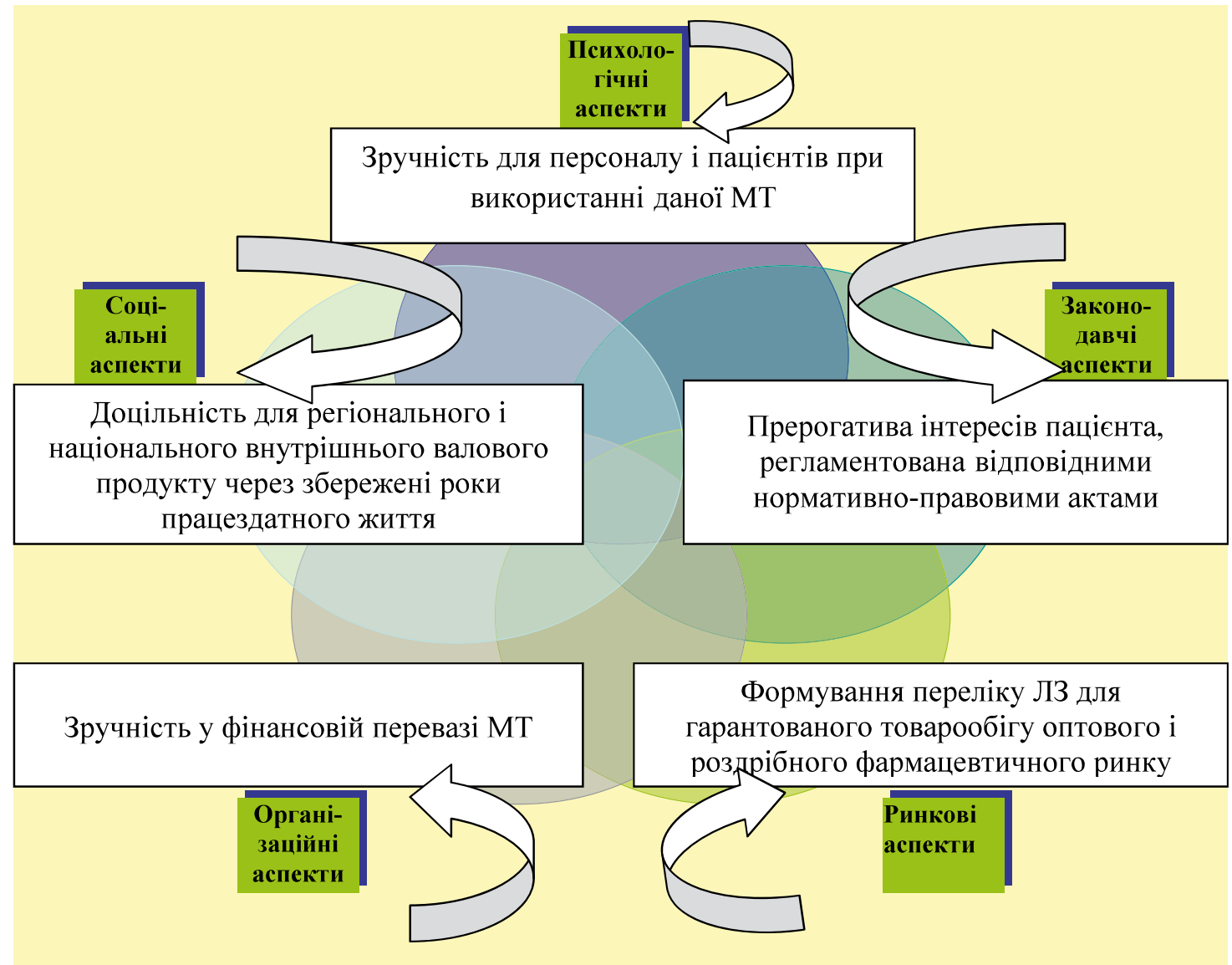

Рис. 1. Основні напрямки теоретичного обґрунтування фрункціонування ОТОЗ для захисту інтересів здоров'я і якості життя людини та суспільства.

у Верховній Раді, тренінгів за участю міжнародних експертів [1, 2, 7]. Однак найбільшим досягненням на шляху просування ОМТ слід вважати створення Експертного комітету з відбору та використання ОЛЗ (далі Експертний комітет) як прообразу національного агентства з ОТОЗ. Відповідно до Положення про Експертний комітет, регламентованого наказом МО3 України № 84 від 11.02.2016 р., «його метою $\epsilon$ здійснення прозорого відбору Л3, до яких належать якісні, ефрективні, безпечні Лз з найвищими показниками економічної доцільності, що необхідні для забезпечення першочергових потреб медичної допомоги населенню в закладах ОЗ для лікування за рахунок коштів державного та місцевих бюджетів»[17]. Отже, на сьогодні Експертний комітет - це дорадчий орган при МО3, який не працює на постійній основі через фрінансові обмеження, що суттєво звужує його діапазон прийнятих у світі функціональних можливостей, а його компетенції в Україні стосується виключно відбору ОЛЗ (наказ МО3 № 1050 від 07.10.2016 р. «Про затвердження положення про здійснення відбору ЛЗ для внесення до національного переліку ОЛЗ») [18].

Однак опрацювання літературних джерел виявило, що зарубіжні агентства з ОМТ мають значно шир- ший спектр фрункцій та мають виражену національну специфріку. На наступному етапі інфрормаційного пошуку нами було вивчено структуру агентств з ОМТ у різних країнах (табл. 2).

За даними літератури подібні національні агентства фрункціонують у ряді інших країн: Ірландії Управління 3 питань медичної інформації та якості медичної допомоги та Національний центр фрармакоекономіки; Шотландії - Шотландська рада 3 медичних технологій; Норвегії - Норвезьке агентство 3 Л3; Австрії - Інститут ОМТ імені Людвіга Больцмана; Австралії - Консультативний комітет з медичного обслуговування [15].

Отже, на сьогодні агентства з ОТОЗ працюють як у країнах, які першими започаткували цей науковий підхід (США, Канаді, Австралії, ЄС), так і країнах із перехідною економікою (Угорщині, Польщі, Латвії, Російській Федерації). Майже всі країни Центральноєвропейського регіону створили орган із проведення ОМТ або його створення планується найближчим часом [15].

Водночас діяльність зарубіжних регіональних агентств з ОТОЗ включає: підготовку звіту про проведену ОТОЗ, проведення прискореної ОТОЗ, написання методологічних вказівок і клінічних рекомендацій,

ISSN 2312-0967. Pharmaceutical review. 2016. № 4 
Таблиця 2. Характеристика національних агентств з ОМТ у різних країнах

\begin{tabular}{|c|c|}
\hline Країна, агентство & Характеристика \\
\hline $\begin{array}{l}\text { США, Агентство з охорони } \\
\text { здоров'я і якості досліджень }\end{array}$ & $\begin{array}{l}\text { У } 1980-х \text { рр. з ініціативи Національної академії наук США була створена Рада } \\
3 \text { технологій в ОЗ. У } 1989 \text { р. - Агентство політики ОЗ та досліджень, яке є } \\
\text { установою у департаменті ОЗ і соціальних служб США, згодом - Агентство з } \\
\text { ОЗ і якості досліджень. Веде базу ефективних і неефективних засобів в О3, } \\
\text { впроваджує ії у клінічну практику і політику ОЗ. }\end{array}$ \\
\hline $\begin{array}{l}\text { Канада, Канадське агентство } 3 \\
\text { лікарських засобів і медичних } \\
\text { технологій }\end{array}$ & $\begin{array}{l}\text { У Канаді запровадження ОМТ почалось у провінції Квебек у } 1988 \text { р. з організації } \\
\text { Ради з ОТОЗ. На державному рівні оцінка ефективності, безпеки, економічної } \\
\text { доцільності МТ почала проводитись Координуючим офрісом з ОМТ Канади у } \\
1989 \text { р. }\end{array}$ \\
\hline $\begin{array}{l}\text { Великобританія, Національний } \\
\text { інститут О3 та удосконалення } \\
\text { медичного обслуговування, } \\
\text { NICE }\end{array}$ & $\begin{array}{l}\text { NICE розробляє керівні матеріали в } 3 \text { напрямках: 1) використання МТ в рамках } \\
\text { CO3; 2) лікування певних захворювань і догляду; 3) зміцнення здоров'я та } \\
\text { профрілактики хвороб. } 32002 \text { р. національні служби ОЗ законодавчо зобов'язані } \\
\text { фінансувати лише ті лП і методи лікування, які були рекомендовані NICE }\end{array}$ \\
\hline $\begin{array}{l}\text { Швеція, Шведська рада з } \\
\text { оцінки технологій в охороні } \\
\text { здоров'я }\end{array}$ & $\begin{array}{l}\text { Шведська рада надає перевагу профілактиці, діагностиці соціальних і } \\
\text { поширених хвороб: пріоритетними є ті МТ, які представляють достатню } \\
\text { кількість наукових обґрунтувань; мають суттєве значення для здоров'я людей } \\
\text { та їх якості життя; стосуються багатьох і є спільною проблемою О3 }\end{array}$ \\
\hline $\begin{array}{l}\text { Фінляндія, Фінське бюро з } \\
\text { оцінки МТ О3 }\end{array}$ & $\begin{array}{l}\text { Створено як державний департамент при МО3 в } 1995 \text { р. Його основне завдання } \\
\text { - підтримка та координація робіт з оцінки технологій в О3. }\end{array}$ \\
\hline $\begin{array}{l}\text { Данія, Данський центр } \\
\text { з визначення та оцінки } \\
\text { технологій охорони здоров'я }\end{array}$ & $\begin{array}{l}\text { У } 1996 \text { р. данський комітет ОТОЗ розробив першу національну стратегію, } \\
\text { у } 1997 \text { р. - створено агентство з національної стратегії із ОТО3, яке містить } \\
\text { наукову і стратегічну консультативні ради }\end{array}$ \\
\hline $\begin{array}{l}\text { Бельгія, Центр вивчення } \\
\text { охорони здоров'я }\end{array}$ & $\begin{array}{l}\text { Центр створено для підтримки політики у сорері О3 і прийняття рішень, він } \\
\text { виконує дослідження в 3-х напрямках: 1) ОТО3; 2) сумлінна клінічна практика; } \\
\text { 3) підтримка медичних досліджень }\end{array}$ \\
\hline Франція, Вища рада О3 & $\begin{array}{l}\text { Вища рада О3 об'єднала агентства з акредитації та оцінки в ОЗ і комітети, } \\
\text { відповідальні за оцінку лп і методики відшкодування витрат послуг; розділена } \\
\text { на підрозділи: стратегічного планування, боротьби } 3 \text { корупцією, медичних } \\
\text { приладів та технологій; економічних оцінок, догляду і підтримки пацієнтів при } \\
\text { хронічних хворобах, поліпшення клінічної практики і безпеки пацієнтів }\end{array}$ \\
\hline $\begin{array}{l}\text { Німеччина, Інститут якості } \\
\text { та ефрективності медичної } \\
\text { допомоги }\end{array}$ & $\begin{array}{l}\text { Основними завданнями агентства } є \text { наукові дослідження; складається } 38 \\
\text { відділів, які проводять незалежні дослідження безпеки і ефективності лп та } \\
\text { МТ; видає бюлетені медико-санітарної інорормації для широкої громадськості }\end{array}$ \\
\hline $\begin{array}{l}\text { Нідерланди, Комітет } 3 \\
\text { визначення відшкодування } \\
\text { вартості медичних продуктів } \\
\text { Ради з медичного страхування }\end{array}$ & $\begin{array}{l}\text { Розвиток ОМТ почався у 1980-х рр. з оцінок найвитратніших технологій. На } \\
\text { сьогодні ОМТ широко застосовується як при фрормуванні клінічних настанов, } \\
\text { програм з ОЗ, промоції здорового способу життя, так і для оцінки госпітальних } \\
\text { закупівель дороговартісних ЛП. Об'єктивну оцінку лП чи МТ надає комісія, яка } \\
\text { складається з членів Комітету; критичний висновок розробляє комісія з членів, } \\
\text { призначених МО3 }\end{array}$ \\
\hline $\begin{array}{l}\text { Угорщина, Офріс } \\
\text { медичних технол } \\
\text { Національного ін } \\
\text { стратегічних дос }\end{array}$ & $\begin{array}{l}\text { Створено у } 2004 \text { р. як незалежний заклад для покращення використання } \\
\text { ресурсів в ОЗ. Розглядає доказові клінічні та економічні дані інадає рекомендації } \\
\text { Фармацевтичному відділу Фонду національного медичного страхування, що } \\
\text { приймає кінцеве рішення щодо відшкодування вартості ЛП або МТ }\end{array}$ \\
\hline $\begin{array}{l}\text { Польща, Агенція з оцінки } \\
\text { медичних технологій }\end{array}$ & $\begin{array}{l}32003 \text { р. фуунцціонує Товариство Центральної та Західної Європи з ОТОЗ та } \\
\text { Агенція з ОМТ. На основі висновків останньої організації МОЗ встановлює } \\
\text { рівень відшкодування вартості ЛП і МТ, враховуючи такі критерії: важливість } \\
\text { для суспільства; наявність аналогів на ринку; безпека; поширеність хвороби; } \\
\text { вплив ЛП на медичні витрати }\end{array}$ \\
\hline $\begin{array}{l}\text { Словаччина, Комітет } 3 \\
\text { класифрікації }\end{array}$ & $\begin{array}{l}\text { МОЗ приймає рішення щодо відшкодування вартості ЛП чи обмеження показань } \\
\text { до застосування на основі висновків Комітету з класифікації. МОЗ спільно із } \\
\text { Центральним комітетом з раціональної фрармакотерапії регулярно працює над } \\
\text { настановами } 3 \text { діагностики і терапії захворювань, що містять, крім клінічних, } \\
\text { також економічні аспекти [15] }\end{array}$ \\
\hline
\end{tabular}

а також освітню діяльність. Отже, регіональна ОТОЗ $€$ невід'ємною частиною систем О3. Використання міжнародного досвіду допоможе впровадити дану систему в Україні та поліпшити якість медичної допомоги на регіональному рівні [11].

Діяльність закордонних локальних підрозділів 3 ОТОЗ - при лікувально-профрілактичному закладі
(ЛПЗ) - включає: складання звітів про проведену ОТОЗ, проведення прискореної ОТОЗ, консультування керівництва ЛПЗ з клініко-економічної доцільності використання технологій. У різних країнах прийнята своя структура звіту з ОТЗ на локальному рівні і затверджений свій порядок його підготовки. У штат підрозділу з ОТОЗ можуть входити 7-10 фрахів-

ISSN 2312-0967. Фармацевтичний часопис. 2016. № 4 
ців (лікарі, епідеміологи, провізори (загальні, клінічні, госпітальні), економісти О3, статистики, юристи, фрахівці з інформаційних технологій), також активно залучаються зовнішні консультанти. Дані підрозділи з ОТОЗ $є$ серйозною підмогою для керівництва лПЗ в прийнятті рішень із закупівель МТ, що допоможе поліпшити якість медичної допомоги на локальному рівні О3 [12].

Тому за аналогією до зарубіжного досвіду функціонування систем ОМТ вважаємо за доцільне рекомендувати і в Україні впровадження трирівневої моделі їі агентств. Розподіл джерел функціонування також варто запозичити. На рисунку 2 представлено пропоновану схему моделі впровадження ОТОЗ.

Тим більше, що у вітчизняній СО3 загалом і фрармації зокрема $є$ позитивна практика фрункціонування трирівневих систем - фрормулярної, фрармаконагляду, забезпечення якості Лз:

наказом МОЗ України від 22.07.2009 р. № 529 «Про створення формулярної системи забезпечення Л3 закладів ОЗ» регламентовано, що Державна фрормулярна система України впроваджує у медичну практику фрормуляри 3-х рівнів: державний формуляр; регіональний фрормуляр; локальний формуляр лЗ закладу ОЗ [19];

наказом МО3 України від 27.12.2006 р. № 898 «Про затвердження Порядку здійснення нагляду за побічними реакціями ЛЗ, дозволених до медичного застосування» визначено, що в Україні державна система фармаконагляду представлена 3-ма ланками: центральною (Департамент післяреєстраційного нагляду у складі ДП «Державний експертний центр МОЗ України», далі - ДЕЦ); регіональною (регіональні відділення ДЕЦ, що фрунціонують в усіх об- ластях України і м. Києві); локальною (особи, відповідальні за здійснення фармаконагляду в закладах О3) [20];

вітчизняна система забезпечення якості ЛЗ побудована за принципом централізації з адміністративною підпорядкованістю складових і має 3 рівні: національний (Державна служба України з ЛЗ, ДЕЦ); регіональний (територіальні підрозділи Державної служби України з ЛЗ і контролю за наркотиками); мікроекономічний (рівень суб'єктів господарювання) [21, 22].

Окрім того, проводяться заходи щодо упорядкування номенклатури закладів О3 в Україні та їх розмежування за рівнями надання медичної допомоги: первинна, вторинна, третинна [23].

А запровадження ОТОЗ в Україні необхідно починати із прийняття національної стратегії - теоретичної доктрини - у вигляді відповідної настанови (Косяченко К. Л., 2016 [1]). Наприклад, у Данії [9] вона містить 7 пунктів: включення ОМТ в планування та політичні рішення на всіх рівнях системи О3; визначення пріоритетних тем і вибір напрямку дій при ОТО3; використання результатів міжнародних ОМТ; аналіз потреби в наукових дослідженнях для подальшого розвитку МТ; координація розвитку в області ОТОЗ; консолідація фрінансових ресурсів; регулярна оцінка і коректування.

Подальшим кроком для реалізації національної стратегії ОТОЗ повинно стати створення всеукраїнського агентства з ОТОЗ. Якщо продовжувати брати Данію у цьому питанню за приклад, то їхнє національне агентство з ОТОЗ містить дві консультативні ради: Науково-консультативну (10 дослідних відділень: статистики, економіки, організації, епідеміології, окремих медичних напрямків тощо) і Стратегіч-

\section{НАПНОНАЛЬНЕ АГЕНТСТВО ОТОЗ}

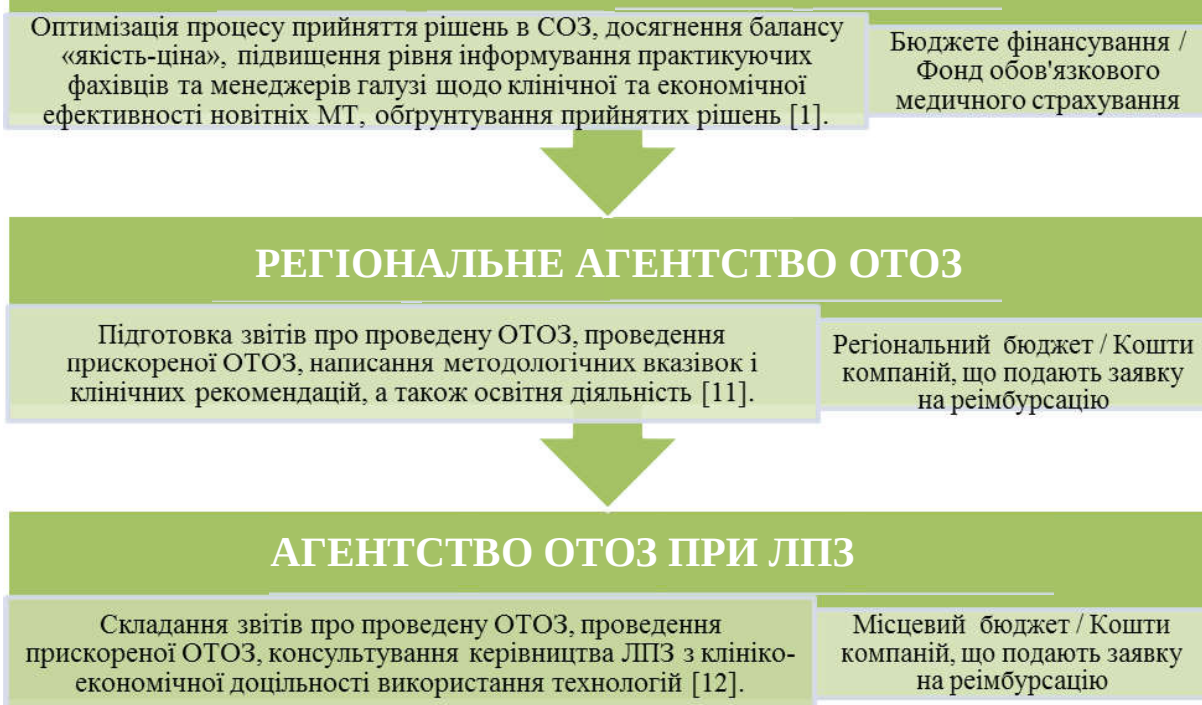

Рис. 2. Орієнтована модель фрункціонування ОТОЗ на різних рівнях надання медико-фрармацевтичної допомоги населенню з пропонованим розподілом завдань та фрінансуванням.

ISSN 2312-0967. Pharmaceutical review. 2016. № 4 
ну (20 представників зацікавлених сторін: наукових установ, органів О3, різних фрахівців) [9].

У свою чергу, у штат регіонального чи локального підрозділу з ОТОЗ можуть входити 7-10 фахівців (лікарі, епідеміологи, провізори (загальні, клінічні), економісти О3, статистики, юристи, фрахівці з інорормаційних технологій), також можуть залучатися зовнішні консультанти [11, 12].

Аналіз підпорядкування національних органів 3 ОТОЗ у різних країнах виявив, що основна мета їх функціонування - незалежна експертиза, тобто вони, як правило, фрінансуються з державного бюджету, однак $€$ або громадськими радами, або незалежними відділеннями менеджменту О3.

Тому і в Україні для фрінансування центрального агентства з ОТОЗ доцільно передбачити кошти державного бюджету та майбутнього фронду обов'язкового медичного страхування (ОМС). Водночас фрінансування регіонального чи локального агентства з ОТОЗ повинно допускати, окрім коштів місцевих бюджетів, і кошти компаній, що подаватимуть заявку на реімбурсацію вартості своїх л3 [1] (особливо це запрацює при запровадженні ОМС). Тобто у будь-якому разі питання додаткового фрінансування усієї СО3 є першочерговим і при обговоренні питання фрінансування агентств з ОТОЗ, оскільки країни, які мають позитивну практику ОТО3, не обмежуються лише бюджетним фрінансуванням медичної і фрармацевтичної допомоги населенню. Власне необхідність фрінансування лише ефективних МТ з різних страхових фондів та ріст витрат на них стали основними причинами розвитку ОТОЗ.

Тому, як і у випадку формулярної системи як складової ОТОЗ, без залучення додаткових джерел фрінансування СО3 (ОМС, благодійних фондів, асоці-

\section{Список літератури}

1. Барміна Г. Впровадження НТА: по якому шляху піде Україна [Електронний ресурс] / Г. Барміна // Аптека. 2016. - № 1029. - Режим доступу : http://www.apteka.ua/ article/362642.

2. Лук'янчук $€$. Оцінка медичних технологій: вимірювання вартості та результатів лікування [Електронний ресурс] / Є. Лук'янчук // Аптека. - 2016. - № 1050. - Режим доступу : http://www.apteka.ua/ article/380050.

3. Kristensen F. B. EUnetHTA and health policy-making in Europe [Text] / F. B. Kristensen // Eurohealth. - 2006. № 12 (1). - P. 36-38.

4. 4. Как добиться большей практической значимости оценок технологий здравоохранения? Краткий аналитический обзор. [Электронный ресурс] / C. Sorenson, M. Drummond, R. Busse, F. B. Kristensen. - ВО3, ВОЗ от имени Европейской обсерватории по системам и политике здравоохранения, 2008. - 32 с. Режим доступа:

5. Варавикова Е. А. Оценка медицинских технологий ацій і товариств пацієнтів, які займаються пошуком коштів для своїх членів) розробки будь-яких моделей ОТОЗ будь-якого рівня залишаться нежиттєздатними, оскільки, без реімбурсації вартості ефективні, якісні і безпечні МТ залишаться недоступними для більшості громадян України [24]. За аналогією до фрормулярної системи, для фрунціонування якої в Україні вже зроблено достатньо багато і у законодавчому плані, і у плані випусків державних формулярів лз (які однак необхідно формувати за результатами ОМТ) доцільно продовжити вітчизняні напрацювання з ОТОЗ. А для цього необхідно створити їх координатора - національне агентство з ОТОЗ, аргументом на користь якого виступає позитивний закордонний досвід.

Висновки. Використання міжнародного досвіду функціонування системи ОТОЗ допоможе впровадити дану систему в Україні для поліпшення якості медичної і фармацевтичної допомоги населенню на національному, регіональному, локальному рівнях. Для цього необхідно розпочати створення агентств 3 ОТОЗ, які будуть серйозною підмогою для керівництв МO3, регіональних департаментів ОЗ при обласних державних адміністраціях, лПз в прийнятті рішень із закупівель МТ. Для фрінансування агентств з ОТОЗ в Україні найбільш прийнятною є змішана модель. Обґрунтування доцільності створення державного центру з відбору МТ, які підлягатимуть реімбурсації з бюджетів різних рівнів, ми пропонуємо розглядати у площині перетину 5-ти основних аспектів: психологічних, соціальних, законодавчих, організаційних, ринкових. Враховуючи актуальність методології ОМТ для вітчизняної СО3, доцільно продовжити вивчення міжнародного досвіду з ОТОЗ для екстраполяції позитивних її досягнень. за рубежом [Электронный ресурс] / Е. А. Варавикова // Кремлевская медицина. Клинический весник. - 2009. № 1 (94). - С. 74-77. - Режим доступа : http://kremlinmedicine.ru/index.php/km/article/view/567/560

6. Заліська О. М. Фармакоекономіка: теоретичні й практичні напрями у світі та в Україні [Текст] / О. М. Заліська, Б. Л. Парновський // Рациональная фрармакотерапия. - 2010. - № 4 - С.

7. Косяченко К. Л. Методологія оцінки технологій в охороні здоров'я та фрармації: актуальність упровадження в Україні [Текст] / К. Л. Косяченко // Управління, економіка та забезпечення якості в фармації. - 2011. - № 1 (15) - С. 36-41.

8. Немченко А. С. Методика фрармакоекономічної оцінки туберкуліно-діагностики в системі оцінки технологій в охороні здоров'я [Текст] / А. С. Немченко, К. Л. Косяченко, М. В. Подгайна // Фармацевтичний часопис. - 2012. - № 1. - С. 92-96.

9. Воробьев К. П. Национальные агентства оценки технологий здравоохранения в экономически развитых

ISSN 2312-0967. Фармацевтичний часопис. 2016. № 4 
странах [Электронный ресурс] / К. П. Воробьев // Український медичний часопис. - 2013. - № 2 (94). С. 162-172. - Режим доступа: http://www.umj.com.ua/ article/56865/ nacionalnye-agentstva-ocenki-texnologijzdravooxraneniya-v-ekonomicheski-razvityx-stranax.

10. Яковлєва Л. В. Оцінка медичних технологій - позиція держав Європейського союзу [Текст] / Л. В. Яковлєва, О. Я. Міщенко // Рациональная фрармакотерапия. 2013. - № 1 - C. 25-28.

11. Угрехелидзе Д. Т. Анализ международного опыта оценки технологий здравоохранения на региональном уровне [Электронный ресурс] / Д. Т. Угрехелидзе, Р. И. Ягудина, Р. У. Хабриев // Фармакоекономика: Теория и практика. - 2015. - Том 3, № 1. - Режим доступа : . 12. Угрехелидзе Д. Т. Анализ международного опыта оценки технологий здравоохранения на уровне лечебно-профилактических учреждений [Электронный ресурс] / Д. Т. Угрехелидзе, Р. И. Ягудина, Р. У. Хабриев // Фармакоекономика: Теория и практика. - 2015. - Том 3, № 1. - Режим доступа : http://pharmacoeconom.com/ru/ articles/article_151.html.

13. Піняжко О. Б. Методичні підходи до проведення оцінки технологій охорони здоров'я в Україні на основ європейської моделі [Текст] / О. Б. Піняжко, О. М. Заліська // Соціальна фрармація в охороні здоров'я. - 2015. - T. 1, № 2. - C. 44-54.

14. Думенко Т. М. Оцінка технологій охорони здоров'я (НTA) на основі даних доказової медицини [Електронний ресурс] / Т. М. Думенко, О. О. Садовнича - Режим доступу : http://www.dec.gov.ua/site/files/klinika/npk5/30. pdf.

15. Мендрік О. Перспективи використання оцінки медичних технологій в Україні. Досвід провідних країн світу [Текст] / О. Мендрік // Український медичний часопис. - 2010. - № 6 (80) - С. 12-16.

16. Досвід становлення та розвиток управління охороною здоров'я населення країн ЄС [Електронний ресурс] - Режим доступу : http://www.trtmo.te.ua/wpcontent/uploads/2015/upr_oh_zdorov_yes.pdf.
17. Про затвердження Положення про Національний перелік Олз та Положення про експертний комітет 3 відбору та використання ОЛ3: Наказ МОЗ України № 84 від 11.02.2016 р. [Електронний ресурс]. - Режим доступу : http://www.apteka.ua/article/362317.

18. Про затвердження положення про здійснення відбору лз для внесення до національного переліку ОЛ3: наказ МОЗ України № 1050 від 07.10.2016 р. [Електронний ресурс]. - Режим доступу : http://www. apteka.ua/article/390509.

19. Про створення фрормулярної системи забезпечення лікарськими засобами закладів охорони здоров'я: наказ МО3 України № 529 від 22.07.2009 р. [Електронний ресурс]. - Режим доступу : http://zakon3.rada.gov.ua/ laws/show/z1003-09?nreg =z1003-09\&find $=1 \&$ text=\%F0\% B3\%E2\%ED\%B3\& $=0 \& y=0$

20. Про затвердження Порядку здійснення нагляду за побічними реакціями лікарських засобів, дозволених до медичного застосування: наказ МОЗ України № 898 від 27.12.2006 р. [Електронний ресурс]. - Режим доступу : http://zakon0.rada.gov.ua/laws/show/z0073-07.

21. Приходько О. Об'єктивно про фрармаконагляд в Україні [Електронний ресурс] / О. Приходько // Аптека. - 2014. - № 967. - Режим доступу : http://www.apteka.ua/ article/314135.

22. Організація та економіка фрармації. Ч. 1. Організація фармацевтичного забезпечення населення : нац. підруч. для студ. вищ. навч. закл. / А. С. Немченко, В. М. Назаркіна, Г. Л. Панфрілова та ін. ; за ред. А. С. Немченко. - Харків : НФаУ : Золоті сторінки, 2015. - С. 197.

23. Критерії класифрікації закладів О3 за рівнями надання медичної допомоги : методичні рекомендації / Міністерство охорони здоров'я України. Український інститут стратегічних досліджень. - К., 2010. - 21 с.

24. Федяк І. Дослідження взаємозв'язків формулярної системи 3 іншими компонентами системи раціонального фрармацевтичного забезпечення / I. Федяк // Матеріали XII Міжнародного медичного конгресу студентів та молодих вчених. - Тернопіль : Укрмедкнига, 2008. - С. 228.

\section{ПОДХОДЫ К РАЗРАБОТКЕ МОДЕЛИ ФУНКЦИОНИРОВАНИЯ АГЕНТСТВ ПО ОЦЕНКЕ МЕДИЦИНСКИХ ТЕХНОЛОГИЙ В УКРАИНЕ}

\section{И. О. Федяк, А. В. Максименко}

ГВУз «Ивано-Франковский национальный медицинский университет»

Резюме: в статье освещены различные взгляды на трактовку понятия «оценка медицинских технологий»; обоснована актуальность и своевременность создания агентств НТА в Украине на национальном, региональном и локальном уровнях; предложены подходы по разработке модели их фрункционирования. Эти подходы целесообразно рассматривать в плоскости пересечения психологических, социальных, законодательных, организационных, рыночных аспектов защиты интересов отдельного человека и общества в целом.

Ключевые слова: оценка технологий здравоохранения, агентства НТА.

ISSN 2312-0967. Pharmaceutical review. 2016. № 4 


\section{APPROACHES FOR DEVELOPING MODELS OF FUNCTIONING AGENCIES OF HEALTH TECHNOLOGIES ASSESSMENT IN UKRAINE}

\section{O. Fedyak, O. V. Maksymenko}

Ivano-Frankivsk National Medical University

Summary: the article highlights various views on the interpretation of the concept «health technologies assessment»; justifies topicality and timeliness of the creation of agencies for HTA in Ukraine at the national, regional and local levels and proposes approaches for developing models of their functioning. It is advisable to consider these approaches across the intersection of psychological, social, legal, organizational, marketing aspects of the protection of individual's interests and society in whole.

Key words: health technologies assessment, agencies for HTA 